\section{New Immunosuppressive Activity of Dykellic Acid}

\author{
SANG B. HAN ${ }^{a}$, Ho J. LeE ${ }^{a}$, Yung H. KHO ${ }^{a}$, Young J. JEON ${ }^{b}$, \\ SANG H. LEE ${ }^{\mathrm{a}}$, HYUNG C. KIM ${ }^{\mathrm{a}}$ and HWAN M. KIM ${ }^{\mathrm{a}, *}$ \\ ${ }^{a}$ Korea Research Institute of Bioscience and \\ Biotechnology (KRIBB), \\ PO box 115, Yusong, Taejon 305-600, Korea \\ ${ }^{\mathrm{b}}$ Department of Pharmacology, \\ Chosun University School of Medicine, \\ 375 Susukdong, Kwangju 501-709, Korea \\ (Received for publication May 28, 2001)
}

Immunosuppressants are a class of compounds that reduce the effects of an activated immune system. These compounds have been clinically effective at suppressing organ graft rejection and in the treatment of autoimmune diseases. The most widely used immunosuppressants are natural products originally isolated from microorganism cultures. Among these products, cyclosporin A, FK-506, and rapamycin are probably the most well known. ${ }^{1)}$ In our previous study, we isolated dykellic acid from the fermentation broth of Westerdykella multispora F50733 by silica gel and Sephadex LH-20 chromatography and reported that this compound inhibits etoposide-induced apoptosis in U937 cells. Its structure was determined by NMR spectroscopy and X-ray crystallography (Fig. 1). ${ }^{2)}$ Here we demonstrate that dykellic acid has immunosuppressive activity.

\section{Materials and Methods}

\section{Analysis of B Cell Functions}

Lipopolysaccharide (LPS) was used to induce mitogenic stimulation and antibody secretion in B cells, as described previously. ${ }^{3)}$ The proliferation of B cells was induced with $5 \mu \mathrm{g} / \mathrm{ml}$ of LPS, and dykellic acid was then added at concentrations of 3 to $30 \mu \mathrm{g} / \mathrm{ml}$ on Day 0 . After incubation for 3 days, $\mathrm{B}$ cells were pulsed with $1 \mu \mathrm{Ci} /$ well of $\left[{ }^{3} \mathrm{H}\right]$ thymidine (113 Ci/nmol, NEN, Boston, MA, USA) for the last 18 hours and harvested with an automated cell harvester (Inotech, Dottikon, Switzerland). The amount of $\left[{ }^{3} \mathrm{H}\right]$-thymidine incorporated into the cells was measured using a Wallac Microbeta scintillation counter (Wallac,
Turku, Finland). The antibody production of $\mathrm{B}$ cells was induced with $25 \mu \mathrm{g} / \mathrm{ml}$ of LPS, and dykellic acid was added at concentrations of 3 to $30 \mu \mathrm{g} / \mathrm{ml}$ on Day 0 . After incubation for 3 days, the amount of IgM was determined by Suspension Hemolytic ( $\mathrm{SH}$ ) assay, as described previously. ${ }^{3,4)}$ Briefly, immunized cells $(100 \mu \mathrm{l})$ were mixed with complement $(8 \mu \mathrm{l})$ and trinitrophenyl-conjugated sheep red blood cells (sRBC, $25 \mu \mathrm{l}$ ) and incubated at $37^{\circ} \mathrm{C}$ for 1 hour. The amount of hemoglobin released from the sRBCs was measured by absorbance at $540 \mathrm{~nm}$.

\section{Analysis of T Cell Functions}

Antigen-nonspecific and alloantigen-specific proliferation of $\mathrm{T}$ cells was induced with $5 \mu \mathrm{g} / \mathrm{ml}$ of concanavalin $\mathrm{A}$ (Con A) and bi-directional mixed lymphocyte reaction (MLR), respectively. ${ }^{4)}$ The MLR was conducted in 96 well plates in $200 \mu 1$ volumes using spleen cells from $\mathrm{C} 3 \mathrm{H}$ mice $\left(\mathrm{H}-2^{\mathrm{k}}\right)$ and BDF1 mice $\left(\mathrm{H}-2^{\mathrm{d}}\right)$. After incubation for 3 days, cells were pulsed with $1 \mu \mathrm{Ci}$ /well of $\left[{ }^{3} \mathrm{H}\right]$-thymidine for the last 18 hours and the amount of $\left[{ }^{3} \mathrm{H}\right]$-thymidine incorporated into the $\mathrm{T}$ cells measured, as described above. RT-PCR was performed to determine cytokine gene expression changes in $\mathrm{T}$ cells, as described previously. ${ }^{3)} \mathrm{T}$ cells were activated with $5 \mu \mathrm{g} / \mathrm{ml}$ of Con A for 24 hours and total RNA was extracted using an Ultraspec II RNA isolation Kit (Biotech Lab. Inc., Houston, TX). Reverse transcription (RT) of the RNA to cDNA was performed using a GeneAmp RNA PCR kit with $100 \mathrm{ng}$ of total cellular RNA (Perkin Elmer, Branchburg, NJ, USA). The mixture was incubated at $37^{\circ} \mathrm{C}$ for 1 hour, and at $99^{\circ} \mathrm{C}$ for 5 minutes. Subsequently, PCR was carried out with 2.5 units of AmpliTaq DNA polymerase and 10 pmoles of cytokine primers for IL-2 and IL-4. The sequences of the primers used were as follows: IL-2, sense 5'-CTTGCC CAAGCAGGCCACAG-3', antisense 5'-GAGCCTTAT GTGTTGTAAGC-3'; IL-4, sense 5'-GAATGTACCAGG AGCCATATC-3', antisense 5'-CTCAGTACTACGAGT

Fig. 1. Structure of dykellic acid.<smiles>C=C1C=C(CCC(=O)O)C(=O)OC1/C=C/C=C/C</smiles>

* Corresponding author: hwanmook@mail.kribb.re.kr 
AATCCA-3'; $\beta$-actin, sense TGGAATCCTGTGGCATCC ATGAAAC- ${ }^{\prime}$, antisense TAAAACGCAGCTCAGTAA CAGTCCG-3'. PCR was performed in a Bio-Rad Cycler (Bio-Rad Lab., Richmond, CA, USA), and PCR products were electrophoresed on a 3\% Nusieve 3:1 agarose gel and photographed after staining with ethidium bromide.

\section{Analysis of Cytotoxicity}

To measure cytotoxicity, spleen cells were incubated for up to 72 hours in the presence of dykellic acids (3 $30 \mu \mathrm{g} / \mathrm{ml})$. Cells were then stained with propidium iodide (PI, $1 \mu \mathrm{g} / \mathrm{ml}$ ) and their viability was measured on a flow cytometry apparatus (BRYTE HS ${ }^{\mathrm{TM}}$, Hertfordshire, UK) ${ }^{4)}$

\section{Results and Discussion}

Among the many immune cells, two main classes of lymphocytes, $\mathrm{B}$ and $\mathrm{T}$ cells, play an important role in initiating the immune response to a transplant or a selfcomponent. We first investigated the effect of dykellic acid on the IgM antibody production and the proliferation of $\mathrm{B}$ cells. Dykellic acid strongly inhibited LPS-induced B cell proliferation (Fig. 2A) and the polyclonal IgM antibody production (Fig. 2B) of B cells in a dose dependent manner. Dykellic acid also inhibited the proliferation of $T$ cells in response to Con A (Fig. 3A) and alloantigen in MLR (Fig. 3B). Furthermore, dykellic acid also inhibited the IL-2 and IL-4 gene expression of Th cells (Fig. 3C). Finally, we verified that dykellic acid did not induce cell death by quantifying cell death by propidium iodide dye uptake assay. As shown in Fig. 4, dykellic acid did not induce cell death at the fully active concentration of $30 \mu \mathrm{g} / \mathrm{ml}$. In addition, this compound did not affect the growth of 14 kinds of cancer cells such as HT-29, HT1080, A549, UO31, B16F10, SNB75, UACC 62, SW620, NCI-H23, MM231, PC-3, ACHN, P388, and EL4, showing more than $100 \mu \mathrm{g} / \mathrm{ml}$ of $50 \%$ growth inhibition value (data not shown).

In the present study, the immunosuppressive activity of dykellic acid is described for the first time. Dykellic acid efficiently inhibits the immune functions of $B$ and $T$ cells, and its immunosuppressive activity is not due to the cytotoxicity. Microorganism-originated immunosuppressants, such as cyclosporin A, FK-506 and rapamycin, act selectively on different stages of the $T$ cell and $B$ cell activation cycles. Both CsA and FK-506 bind to cytoplasmic receptors (cyclophylin and FK-binding protein 12 , respectively) and the resulting complexes inactivate
Fig. 2. Dykellic acid inhibits B cell functions.
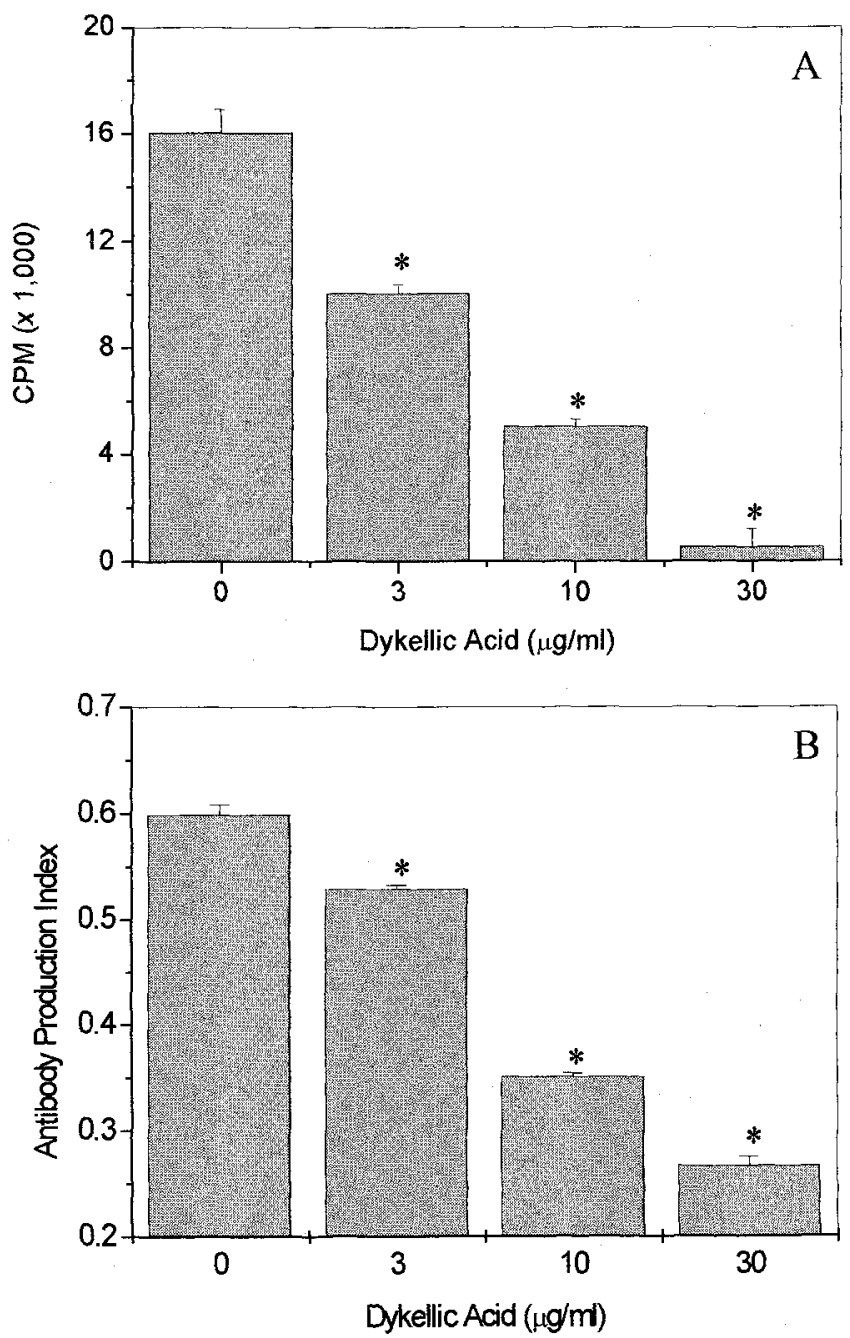

\begin{abstract}
Lipopolysaccharide (LPS) was used to induce mitogenic stimulation and antibody synthesis and secretion in B cells. LPS was used at $5 \mu \mathrm{g} / \mathrm{ml}$ and dykellic acid from 3 to $30 \mu \mathrm{g} / \mathrm{ml}$. After incubation for 3 days, the proliferation (A) and the production of polyclonal IgM antibody (B) of B cells were measured. Significance was determined using the Student's $t$-test versus the control group $(* p<0.01)$.
\end{abstract}

calcineurin, a pivotal enzyme in IL-2 gene transcription. ${ }^{6)}$ Unlike cyclosporin A and FK-506, rapamycin inhibits both IL-2-driven $\mathrm{T}$ cell activation and CD40-mediated B cell activation. ${ }^{1,7)}$ Rapamycin inhibits the protein serine kinase mammalian target of rapamycin (mTOR), which has been implicated in the IL-2-dependent signaling pathway, and blocks G1-to-S phase progression of the cell cycles. In the present study, we demonstrate that the cell-type selectivity of dykellic acid is similar to that of rapamycin, and differs 
Fig. 3. Dykellic acid inhibits $\mathrm{T}$ cell functions.
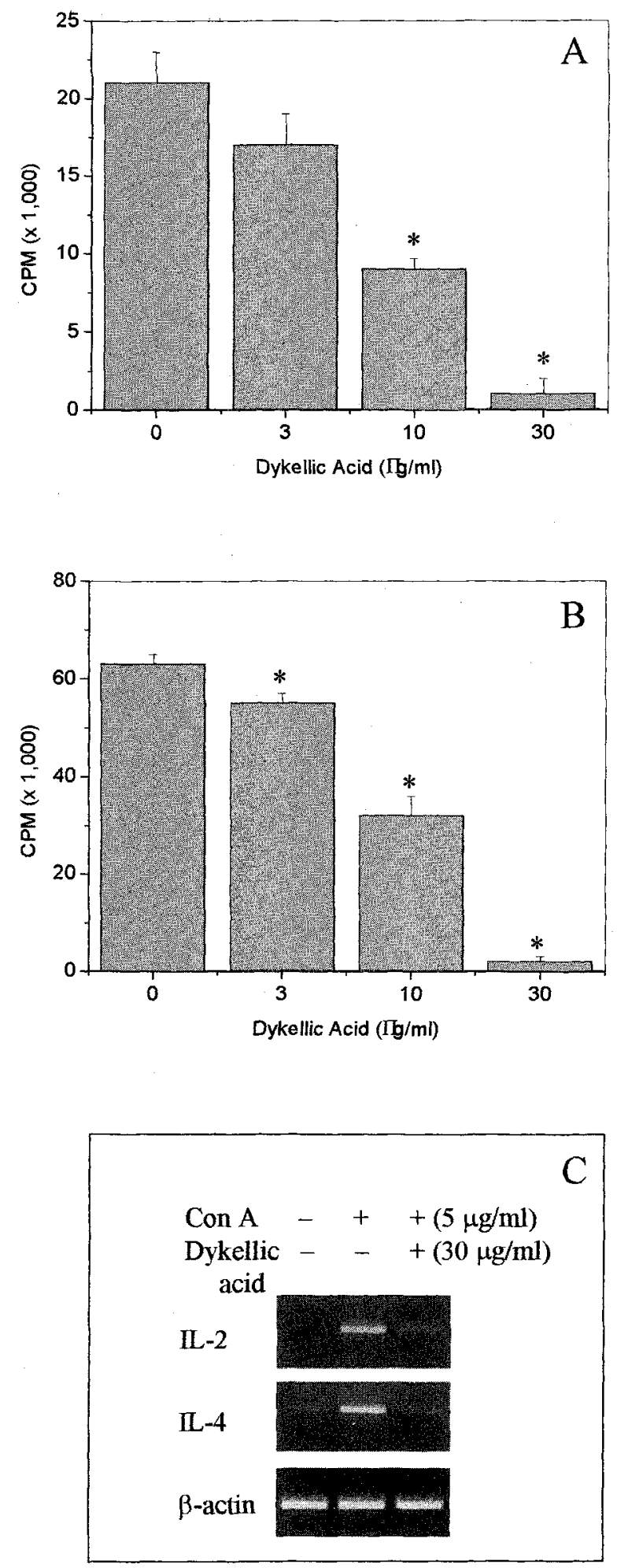

Antigen-nonspecific and the alloantigen-specific proliferation of $\mathrm{T}$ cells were induced with $5 \mu \mathrm{g} / \mathrm{ml}$ of Con A (A) and MLR (B), respectively. RT-PCR was performed to measure the expression level of IL-2, IL4 , and $\beta$-actin (C). Significance was determined using the Student's $t$-test versus the control group $\left({ }^{*} p<0.01\right)$.
Fig. 4. Cytotoxicity of dykellic acid.

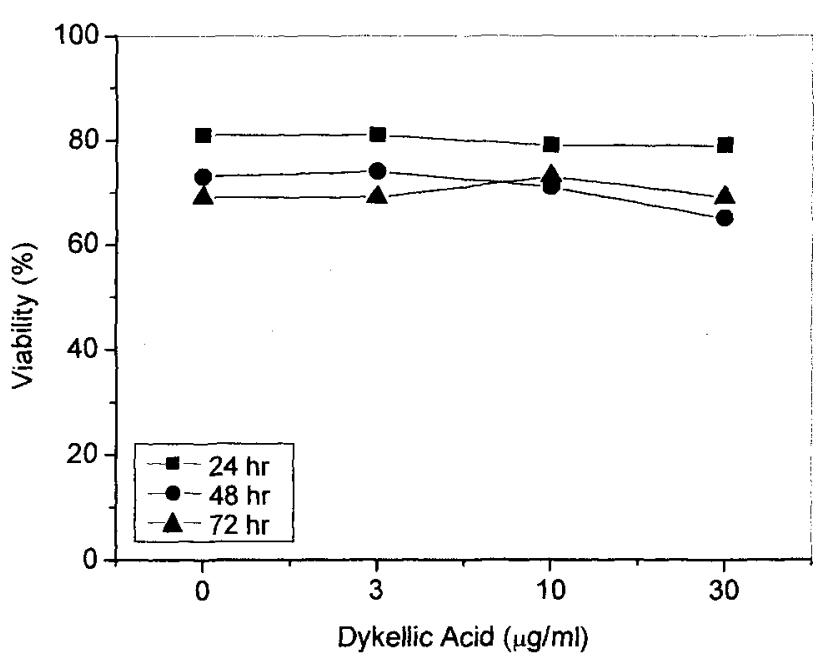

Spleen cells were incubated for up to 72 hours with $3 \sim 30 \mu \mathrm{g} / \mathrm{ml}$ of dykellic acid and then were stained with $1 \mu \mathrm{g} / \mathrm{ml}$ of propidium iodide. Cell viability was measured by flow cytometry.

from that of cyclosporin A. Based on this information, a further study will be directed at identifying the mode of action of dykellic acid with regard to IL-2-dependent signaling and cell cycle phase transition.

\section{References}

1) ABraham, R. T. \& G. J. WiederRecht: Immunopharmacology of rapamycin. Annu. Rev. Immunol. 14: 483 510, 1996

2) Lee, H. J.; C. H. Lee, M. C. Chung, H. K. Chun, J. S. RHEE \& Y. H. KHO: Dykellic acid, a novel apoptosis inhibitor from Westerdykella multispora F50733. Tetrahedron Lett. 40: 6949 6950, 1999

3) Han, S. B.; Y. H. KiM, C. W. Lee, S. M. PARK, H. Y. LeE, K. S. AHN, I. H. KIM \& H. M. KIM: Characteristic immunostimulation by angelan isolated from Angelica gigas Nakai. Immunopharmacology 40: 39 48, 1998

4) HAN, S. B.; H. M. KIM, Y. H. KIM, C. W. LEE, E. S. JANG, K. H. Son, S. U. KIM \& Y. K. KIM: T-cell specific immunosuppression by prodigiosin isolated from Serratia marcescens. Int. J. Immunopharmacol. 20: $1 \sim 13,1998$

5) Denton, M. D.; C. C. Magee \& M. H. Sayegh: Immunosuppressive strategies in transplantation. Lancet 353: 1083 1091, 1999

6) Behbod, F.; R. A. ERWin-COHEN, M. WANG, B. W. Trawick, X. Qu, R. Veranl, B. D. Kahan, S. M. STEPKOWSKI \& R. A. KIRKEN: Concomitant inhibition of 
janus kinase 3 and calcineurin-dependent signaling pathways synergistically prolongs the survival of rat heart allografts. J. Immunol. 166: 3724 3732, 2001

7) Sakata, A.; K. Kuwahara, T. Ohmura, S. Inui \& N.
SAKAGUCHI. Involvement of a rapamycin-sensitive pathway in CD40-mediated activation of murine $\mathrm{B}$ cells in vitro. Immunol. Lett. 68: 301 309, 1999 